\title{
Addressing Challenges of Urbanization for Quality of Growth
}

Urbanization is closely related to the process of industrial structure transformation. New industries, along with the expansion and diversification of existing ones, create employment opportunities, drawing workers and managers to live in areas where such industries are located. Urbanization takes place accordingly, enabling higher productivity of these industries and, in turn, creating new demand for goods and services by industries that will employ more workers, thereby leading to further industrial transformation and urbanization. As such, industrial structure transformation and urbanization are intrinsically self-reinforcing. In this way, urbanization can be considered a part of the transformation process.

From this point of view, ADB's (2013) discussion of the relationship between industrial transformation and urbanization is very illuminating. It highlights five components of structural transformation: "reallocation of factors of production; diversification, upgrading, and deepening of the production and export baskets; use of new production methods and processes and different inputs; urbanization; and social changes" (3). This approach is confirmed by statistical analysis demonstrating that "urbanization and GDP per capita tend to move in sync as countries develop, thus creating a consuming class that drives demand. In all known cases of high and sustained growth, urban manufacturing and services led the process, while increases in agricultural productivity freed up labor to move to the cities" (3). However, the ADB document emphasizes two challenges of urbanization, in that, "Because urbanization is one of the most important enablers of rapid growth, countries that want to grow fast must learn how to make urbanization work well. The first challenge is to foster the growth of high productivity activities that benefit from agglomeration and scale economies in developing-country cities. The second involves managing the likely side effects of the economic success of cities, i.e., urban poverty, pollution, congestion, and high prices of land and housing, as well as regional inequality. Meeting this second challenge is essential for mitigating the divisive impacts of successful economic growth and spreading the benefits of higher economic productivity widely" (25).

Related to these challenges of urbanization is Goal 11 of The Sustainable Development Goals (SDGs). It calls on member states to "[M]ake cities and human settlements inclusive, safe, resilient and sustainable." A specific target of this Goal is to, "by 2030, enhance inclusive and sustainable urbanization and capacity for participatory, integrated and sustainable human settlement planning and management in all countries." The Goal addresses the serious context of urbanization in developing countries. In many developing countries, urban conditions continue to be diffuse and disorganized. The lack of proper planning generates unsafe and dangerous conditions for everyday life and blocks access to jobs as well as educational, and cultural 
opportunities (de Souza et al. 2018). Moreover, according to the UN High-Level Panel for the post-2015 Agenda (henceforth, HLP), by 2030, there will be over one billion more urban residents in the world and, for the first time, the number of rural residents will start to shrink (HLP 2013).

Manuh and Yemeru (2019) sketch out the process of urban transition, which is currently taking place in Africa on a scale unprecedented in history. The number of urban dwellers is expected to increase by almost 900 million in the next 35 years. By 2050 Africa is projected to have an urban population of 1.48 billion, with a further 1 billion rural dwellers (380). They argue that "the manner in which urbanization is planned and managed today will play a critical role in the quality of growth in Africa over the coming decades, and in particular the achievement of structural transformation through industrialization." They further emphasize that, "in this respect, although Africa's urbanization offers possibilities to advance key economic, social, and environmental policy priorities, its current trajectory poses significant risks for the quality of growth" (376).

The World Development Report 2016: Digital Dividend argues that rapid urbanization in the developing world "creates urgency to get our cities 'right' because global response to our most pressing challenges - from climate change to rising inequality - will likely succeed or fail in cities" (World Bank 2016, 240). We could consider this concept of getting cities "right" as realizing "quality urbanization."

From a quality of growth perspective, one of the most effective approaches that can be used to address these urban challenges is "reurbanization with land readjustment." This chapter aims to provide insights into the main features of the land readjustment approach, focusing on its effectiveness, advantages, and challenges. First, in Sect. 6.1, this chapter will discuss the main characteristics of land readjustment and its relevance for urbanization, drawing from experiences in Japan. In Sect. 6.2, it will analyze how land readjustment can enhance the inclusiveness, sustainability, and resilience of urban development. Section 6.3 will discuss experiences of land readjustment in developing countries, focusing on the remarkable case of Medellin, Colombia. It will review international cooperation in introducing land readjustment in Sect. 6.4. Finally, some concluding remarks will be offered.

\subsection{Land Readjustment and Re-urbanization as an Approach to Making Cities Inclusive, Safe, Resilient, and Sustainable: Key Issues}

As cited above, Goal 11 of SDGs calls on member states to "Make cities and human settlements inclusive, safe, resilient and sustainable." We therefore need to find effective ways and means to realize Goal 11. One method or practice that could provide an effective approach to this goal is "land readjustment." This approach could help to address the challenges of improving urban conditions in order to achieve urbanization while promoting more desirable attributes. Based on experiences in Japan and other countries, this section explores how these experiences have been applied and further improved in a range of developing countries through Japan's international cooperation programs, as well as those of other organizations.

There are two main known tools that can be used to address the demand to reorganize urban structures and land patterns. The first of these is eminent domain, or expropriation, by which private property is compulsorily purchased for public usage or reallocated to third parties who will assign it to public or civic uses. The other is land readjustment. This has been promoted as an innovative land assembly method to overcome reorganization problems faced - especially by developing countries (Sorensen 2009; de Souza 2018, 17).

Japan is one of several countries that have managed over the past decades to implement solutions to urban problems faced by all developing countries: migration from rural areas to urban centers, urban expansion and uncontrolled 
growth, and countless environmental problems. Throughout this entire process - which took place over more than a century-methods for territorial planning were developed and institutionalized. This included negotiation processes to control urban growth, and implementation of infrastructure and land pattern changes - especially through land readjustment practiceswithout the widespread use of expropriation (de Souza 2018, 22). Therefore, Japan might be considered a pioneering country in mainstreaming the land readjustment approach in urban development policy.

The usage of land readjustment in Japan is broad in scope and purpose. It can be divided into five categories: control of urban sprawl, development of new towns, urban rehabilitation, development of complex urban infrastructure, and disaster reconstruction (de Souza 2018, 2324). Indeed, the scale of its application in Japan is outstanding: "Widely applied throughout the country, land readjustment is known as the 'mother of urban planning' in Japan. Several project modalities have been introduced and improved over the past century, transforming 10,909 areas, or 329,249 ha (as of March 2013), which represents approximately $1 / 3$ of the whole country's urban area" (de Souza and Ochi 2018, 36). Furthermore, land readjustment has been a driving force behind post-disaster reconstruction, in particular (Yanase 2018, 42).

Definitions of land readjustment are diverse and differ according to country contexts. However, the essential concepts can be found in the general provisions of the Japanese "Land Readjustment Law" enacted in 1954. According to this law, land readjustment means to alter the shape and land conditions of lots and install or improve public facilities in a city planning area in order to provide better public facilities and increase the usage of each lot.

The following explanation describes land readjustment in terms of its goals and process: "through land readjustment projects, the main contribution is in the form of land that will improve the public realm-roads, parks, sidewalks, sites for public schools and hospitalsand, consequently, increase private land values.
As purchasing land for public facilities can be prohibitively expensive, through the win-win potential of land readjustment, it can be possible to finance and promote projects that would not be possible by any other means. Landowners' property rights, in this sense, still prevail, with smaller size and possible higher total asset value, aiming at the fair distribution of costs and benefits for urban development" (de Souza 2018, 25).

\subsection{Land Readjustment: Characteristics and Relevance for Urbanization in Developing Countries' Quality Growth}

Based on the above-mentioned characteristics, we might ask how land readjustment can facilitate the attainment of the desired attributes of urban development: inclusiveness, safety, resilience, and sustainability. The following sections will discuss some general aspects of land adjustment first, and then consider its contribution to developing countries' urban development, by drawing from one concrete case.

\subsubsection{Land Readjustment and Inclusiveness}

As discussed in Chap. 3, the Framework of Inclusive Growth Indicators (FIGI) asserts that the outcomes of inclusive growth are achieved through three policy pillars. These are sustained economic growth and development of productive jobs and economic opportunities, social inclusion to ensure equal access to economic opportunities by expanding human capacities, and social safety nets to protect the chronically poor and to address the risks and vulnerabilities of the population (ADB 2013).

Land readjustment may bring two significant social benefits in comparison to eminent domain, or expropriation. The first benefit is the preservation of social, cultural and economic networks that are closely tied to a physical location, routines and interactions of everyday life in that 
place, through original community maintenance (de Souza 2018, 17). This is because, in the case of land readjustment, all dwellers (landowners and tenants) remain after project implementation. Community cohesion, or social capital, is maintained or fostered in this approach. The second benefit is the realization of the equitable distribution of costs and benefits in urbanization processes. All property owners (the original residents) contribute by providing a portion of their property to establish public spaces, or by providing land to sell to pay for improved infrastructure. Thus land readjustment can provide a means of working towards a more equitable distribution of both costs and benefits of urbanization (Sorensen 2009, xi; de Souza 2018, 17).

From the perspective of inclusive development, the inclusiveness of land readjustment is clear in indicators such as FIGI, as mentioned above. On the one hand, land readjustment could potentially facilitate opportunities for residents to participate more actively in the economic and social development process through better access to opportunities. For example, new infrastructure constructed in a land readjustment area can enhance connectivity to public transport (new bus stops and so on) and to urban centers, access to higher education or specialized health care, as well as diversified job opportunities. Moreover, land readjustment can secure the public space necessary for basic education and primary healthcare through the landowners' land contribution mechanism.

Furthermore, land readjustment contributes to addressing increasing inequalities that may occur during the process of urbanization. It ensures a fair distribution of the costs and benefits of urban development and avoids the problem of increases in land values (capital gain, or plus valia) being monopolized by large landowners, developers or governments. With the costs of land readjustment mostly borne by beneficiaries, the need to use public funds for urban development can be minimized. Finally, social safety nets to protect the chronically poor and address the risks and vulnerabilities of the population can be enhanced directly or indirectly by land readjustments (as discussed below). In short, land readjustment may help to make urban development inclusive and equitable.

\subsubsection{Land Readjustment and Safety, Resilience, and Sustainability}

One driving force behind post-disaster reconstruction in Japan is land readjustment. After a disaster occurs, people aim to build back more resiliently and stronger than before, or build back better (see Chap. 8), rather than simply trying to rehabilitate the disaster-stricken communities (Yanase 2018, 42). In post-disaster reconstruction, both preservation/cohesion and stronger resilience of communities are essential and, as such, land readjustment has been a powerful driving force.

The improvement of sewage, waste treatment and drainage systems, construction of green belts and parks, and other facilities necessary for the environmental sustainability of the community requires public space for which a land readjustment approach may be effective. Without this approach, the cost of securing land for these investments in public expenditure could be enormous. Cities without facilities for environmental sustainability are likely to suffer from serious air and water pollution and its consequences. Public space and better connectivity, as well as community coherence, are important for the safety of residents and the city as a whole. Furthermore, as discussed below, there have been cases of re-urbanization through land readjustment that have contributed remarkably to improving public safety.

In summary, land readjustment is an approach that can contribute to making cities more inclusive, safe, resilient, and sustainable, as established by the SDGs-especially Goal 11 . However, land readjustment alone cannot assure inclusive development. In order to address urban poverty in slums, several policy measures need to be introduced, together with land readjustment, in slum areas. As such, a comprehensive scheme with a whole range of policies and tools is 
essential. On the other hand, traditional pro-poor approaches may be more effective when they are implemented with land readjustment.

\subsection{Land Readjustment in Developing Countries: Case of Medellin, Colombia}

Urbanization is accelerating in developing countries, where urban sprawl, slums, inadequate urban infrastructure, human insecurity, air and water pollution, and vulnerability to disasters are common. Urban slums continue to expand in high-risk areas. In this context, participation by the urban poor in the development process is constrained by inadequate access to jobs and economic opportunities and by limited access to education and healthcare, undermining the capacity to take advantage of such opportunities. After urban slums are settled and subdivided, whether legally or illegally, it is extremely difficult to rearrange property patterns, and it is both difficult and expensive to ensure land for proper public purposes and facilities. In these circumstances, land readjustment or reurbanization programs that include land readjustment could provide an effective approach to addressing the above-mentioned urban poverty and slums and making cities of developing countries inclusive, safe, resilient, and sustainable.

Additional insights into these aspects can be drawn from an examination of one concrete case from a developing country. In Colombia, Law No 9 was enacted in 1989 in order to introduce urban reform instruments for management and land use planning, conferring on the State the primary role as city builder. During the law's development process, the involvement of the Japan International Cooperation Agency (JICA) was reflected in the incorporation of instruments such as land readjustment and urban redevelopment in particular (Rojas Everhard 2018, 116).

Later, in 1997, a new law (Law No. 388) was enacted, which prompted all Colombian city councils to prepare an urban planning master plan. Japan's ten-year history of cooperation contributed greatly to efforts to establish this new urban planning framework. Former trainees from the JICA country-specific training courses provided a driving force in Colombia's urban planning. In 2003, the Colombian government proposed new urban development projects and asked for the participation of the former trainees. This meant that JICA's support for capacity building in the areas of urban planning and land readjustment was relevant to the Colombian government and its development policies, and the high level of capacity building was recognized (Ochi 2018, 134).

The former JICA trainees worked in administrative institutions of important Colombian cities, including Medellin, Cartagena and Chia, and applied the urban planning and the land readjustment methods they learned. By 2013, land readjustment projects that included urban redevelopment projects had been conducted in five districts, including Medellin, and there were about 50 projects using methods similar to land readjustment that had been undertaken all over the country (Ochi 2018, 134).

Integral improvement of communities (Mejoramiento Integral de Barrios, MIB) in the Juan Bobo area of Comuna no. 2 in the Northeastern zone of Medellín was designed, coordinated, and implemented by the Company of Urban Development (Empresa de Dessarollo Urbano, EDU) between 2004 and 2008. The project targeted dwellings that had been constructed along the banks of the Juan Bobo Stream, with a population of 1,353 (300 families) and a land area of 1.75 ha. MIB is a part of the Integral Slum Improvement Program, a city program that attempted integral slum redevelopment between 2004 and 2007. The project goals were: (i) applying an efficient and flexible planning procedure based on technical criteria adjusted for each micro-territory, (ii) fostering community consensus and participation in generating secure coliving conditions, (iii) improving the whole neighborhood by securing proper financial resources, (iv) improving and legalizing 
residences on the basis of an analysis of demographic dynamics, and (v) improving degenerated land and the environment to help on-site resettlement (Alcaldía de Medellín 2011; Sato 2013, 5). ${ }^{1}$

In 2002, a public gondola-lift transport system called Metro Cable K Line was inaugurated in areas called Comuna no. 1 and Comuna no. 2, providing a 7-min service connecting the hillside neighborhoods of Northeastern Medellín with the Medellín metro system, benefitting approximately 170,000 residents. This provided services to Comuna no. 1 and no. 2, areas where living conditions were the lowest in the city, and constituted a much-needed public intervention. Thus, the blueprint for MIB came to be included in the draft of the city development plan.

Through this project, the following infrastructure works were completed in the public space secured by land readjustment in the Juan Bobo area: sewage pipes $(2.7 \mathrm{~km})$, cleaning of the stream basin $(200 \mathrm{~m})$, stream-edge improvement for pedestrians $\left(1,500 \mathrm{~m}^{2}\right)$, public space and pedestrian mobility improvement and construction $\left(4,500 \mathrm{~m}^{2}\right)$, restoration of the environment $\left(2,000 \mathrm{~m}^{2}\right)$, construction of a bridge to connect parts of the community, and construction of a library and two community salons. At the same time, eight new apartment blocks were constructed and property rights were registered for 118 families. Along with this, 115 houses were improved (Sato 2013, 34).

This re-urbanization project utilizing a land readjustment approach was inclusive: coherence of the community was maintained and fostered through the whole project process and by the construction of two community salons. The conversion of property rights was made not only from land to land (i.e. moving to a new smaller property of approximately the same value) as practiced in Japan, but also from land to building floor in this case (i.e. moving to an apartment of similar value to the land). In addition, all apartment floors were legally registered. With the improvement of roads in the district, together with the construction of the Metro Cable, access to jobs and other economic opportunities substantially improved.
Through the construction of the sewage pipes, cleaning of the Juan Bobo stream basin, and restoration of the environment, the project contributed to the environmental sustainability of the district. The resilience of the community was enhanced, because the high-risk areas where houses were located (for example, where there was a possibility of landslides occurring) were converted into green areas. Furthermore, new apartments were constructed in areas where there was a low risk at a safe distance from the valley through which the Juan Bobo stream runs. Regarding public safety, the only available statistics are for the whole of Medellin city. While considered one of the most dangerous cities in the world at the beginning of the 1990s, the number of homicides per 100,000 persons decreased from 381 in 1991 to 184 in 2002, and just 26 in 2007. Although this decrease cannot be attributed exclusively to urban redevelopment programs, the completion of Metro Cable K and the implementation of these programs in the 2000s coincided with the rapid decrease in the homicide rate. In 2007, the homicide rate in Medellin was lower than the average for Colombia, yet it still remains higher than the capital, Bogota. ${ }^{2}$

The improvement in inclusiveness (better housing, better access to jobs, and education and health facilities), safety, resilience, and sustainability through urban redevelopment with the land readjustment approach may have contributed at least partly to the improvement of the Human Development Index of Comuna no. 1 from 73 in 2004 and 2006 to 79 in 2009. At the same time, the status of Medellin also improved from 79 in 2004 to 80 in 2006, and 85 in 2009.

In short, experiences in Colombia and many other developing countries confirm that the land readjustment approach may provide a fundamental tool for improving poor areas, and in securing land for the poor, together with public spaces for inclusive development. Experiences in Afghanistan, Angola, Bhutan, Brazil, Colombia, India, Indonesia, Mongolia, Nepal, Thailand, Turkey, and Vietnam are analyzed in Chap. 3 of the book, Land Readjustment: Solving Urban Problems through Innovative Approach edited by de Souza 
et al. (2018). In Japan, land adjustment is not usually regarded as a means of addressing issues of poverty (see Ochi 2018, 137). As such, the above finding regarding the relevance of land readjustment for improvement of poor areas is a result of mutual learning toward innovative approaches achieved through international cooperation. In Colombia, the establishment of a land readjustment framework contributed to the country's efforts in urban planning, in which the need to address issues related to urban poverty remains a major concern.

\subsection{International Cooperation for Land Readjustment}

Japanese cooperation for land readjustment has been provided mainly through three schemes or programs: (1) active participation in international conferences and seminars, (2) structured training courses for developing countries' practitioners held continuously in Japan over the past three decades, and (3) technical cooperation with some developing countries carried out together with above-mentioned international seminars or training courses.

Land readjustment became internationally known in the late 1970s. The first International Conference on Land Consolidation was held in 1979, where the term 'land readjustment' was used for the first time. The conference decided to switch away from the term 'land consolidation' to 'land readjustment' after considering the variety of land readjustment projects presented at the conference (see Ochi 2018, 126). The second international conference was held in 1982 in Japan as a commemorative event to celebrate the completion of the post-war reconstruction land readjustment projects in Nagoya City. This conference highlighted the active implementation of land readjustment projects in Japan. After the conference, several international seminars were held in the ASEAN region and other countries, resulting in significant impacts on urban development in Southeast Asian countries. These international seminars came to an end in the year 2000 (see Ochi 2018, 126).
Japan started to provide technical cooperation related to land readjustment during the 1980s, in which the former Ministry of Construction and JICA played a central role. There have been two types of technical cooperation programs in this regard: (1) a full set-type technical cooperation program which includes dispatch of experts and feasibility studies on land readjustment; and (2) training courses and follow-up type support for developing countries to establish their own land readjustment frameworks.

JICA and the former Ministry of Construction (Japan) began to provide training courses on land readjustment in 1983, aiming to disseminate Japan's urban development techniques to developing countries. JICA has continued to provide these training courses until today, with a total of 363 participants from 68 countries attending these courses from 1986 to 2014 (see Ochi 2018, 127).

Based on the experiences of international cooperation over the past three decades, JICA has introduced changes in the training courses, taking a more specific approach, such as the establishment of an institutional land readjustment framework and problem-solving, thus going well beyond a general introductory program of land readjustment. To this end, JICA decided to accept trainees from countries where land readjustment projects are being conducted, and from countries where a government organization is trying to introduce the land readjustment method at home. The training program contents do not focus solely on Japanese experiences of land readjustment but are based on mutual learning with countries that have successfully applied their own land readjustment policies (see Ochi 2018, 138). Triangular cooperation approaches - in which pivotal countries, beneficiary countries and Japan all participateappear to be a promising area (Hosono 2013). Colombia is now acting as the leader (or pivotal country) in land readjustment experiences for Latin American countries, while Thailand is expected to be a leader in Asia.

Recently, some international organizations have become increasingly engaged in international cooperation in land readjustment. For 
example, UN-Habitat incorporates this approach into its cooperation program by paying attention to the participatory and inclusive attributes of land readjustment. This organization also considers land readjustment as a viable tool to enable public and private partnerships for land development. In 2016, the World Bank started to offer online courses in land readjustment (see Ochi 2018, 139).

In these ways, land readjustment has increased its relevance in international cooperation for urbanization, urban redevelopment, and in particular, for the achievement of the SDGsespecially of Goal 11.

\subsection{Concluding Remarks: Land Readjustment and Quality Urbanization}

Land readjustment could provide an effective approach toward realizing "quality urbanization" and attaining Goal 11 of the SDGs. However, land readjustment alone is unlikely to achieve the expected outcomes. It needs to be applied comprehensively and strategically in addressing the issues that face developing countries. This includes not only infrastructure development, slum upgrading and the guarantee of property rights but also urban management, urban governance, climate change mitigation/adaptation, and so forth.

In this regard, it is critical to envisage comprehensive ways of achieving "quality urbanization." that can be adapted to the many diverse realities of developing countries. Further in-depth study is needed, drawing from theoretical and empirical analyses of past experiences. This chapter has provided some substantial insights into recent initiatives and their outcomes. For example, land readjustment in Medellin, Colombia, applied to urban slums, together with several measures implemented in the same period, has achieved substantial improvements within informal settlements in high-risk areas. In general, pro-poor policies, infrastructure for better access to jobs, education and health, and land readjustment could produce synergies and effectively address the challenges faced by urban slums.
Since the mid-2000s, several "smart city" initiatives have been carried out to make cities more sustainable. It is important to note that smart city development projects have recently emphasized both sustainability and inclusion. The World Development Report 2016: Digital Dividend identifies three exemplary practices for smart cities: using data to address the most vulnerable populations (e.g. São Paulo), opening up data to promote accountability (e.g. Nairobi), and using mobile connectivity to enhance civic participation (e.g. Philippines) (World Bank 2016, 241). The alignment of land readjustment projects to these and other initiatives of smart cities appears to constitute a very promising approach.

In summary, land readjustment could provide an important instrument for development and redevelopment of urban areas, and potentially for "quality urbanization," which is essential for quality growth in the contemporary developing world. It is hoped that the discussion provided in this chapter has offered meaningful insights into inclusive, sustainable, and resilient urbanization by identifying the advantages and challenges of land readjustment, and hence, will help with the identification of useful steps toward the attainment of quality growth and poverty reduction realized through such growth.

\section{Notes}

1. This and next four paragraphs are based on Sato (2013) and the author's field survey in Juan Bobo area in 2010.

2. These figures are from Sato $(2013,7)$, based on the data from Empresa de Desarrollo Urbano (EDU).

3. These figures are from Sato $(2013,7)$, based on Rivas $(2011,45)$.

\section{References}

Alcaldía de Medellín (2011) Medellín laboratory-an exhibit of ten ongoing practices. Alcaldía de Medellín, Medellín

Asian Development Bank (ADB) (2013) Framework of inclusive growth indicators 2013. Asian Development Bank, Manila 
de Souza F (2018) Concepts on land readjustment. In: de Souza F, Ochi T, Hosono A (eds) Land readjustment: solving urban problems through innovative approach. JICA Research Institute, Tokyo, pp 15-32

de Souza, F, Ochi T (2018) Land readjustment and the law in Japan. In: de Souza F, Ochi T, Hosono A (eds) Land readjustment: solving urban problems through innovative approach. JICA Research Institute, Tokyo, pp 33-38

de Souza F, Ochi T, Hosono A (eds) (2018) Land readjustment: solving urban problems through innovative approach. JICA Research Institute, Tokyo

High-Level Panel of Eminent Persons on the Post-2015 Development Agenda (2013) A new global partnership: eradicate poverty and transform economies through sustainable development. United Nations, New York

Hosono A (2013) Scaling up south-south cooperation through triangular cooperation. In: Chandy L, Hosono A, Kahras H, Linn J (eds) Getting scale: how to bring development solutions to millions of poor people. Brookings Institution, Washington, DC, pp 236-261

Manuh T, Yemeru EA (2019) Urbanization and quality of growth in Africa. In: Kanbur R, Norman A, Stiglitz JE (eds) Quality of growth in Africa. Columbia University Press, New York, pp 375-397

Ochi T (2018) JICA's technical cooperation and the global dissemination of land readjustment. In: de Souza F, Ochi T, Hosono A (eds) Land readjustment:

Open Access This chapter is licensed under the terms of the Creative Commons Attribution-NonCommercialNoDerivatives 4.0 International License (http:// creativecommons.org/licenses/by-nc-nd/4.0/), which permits any noncommercial use, sharing, distribution and reproduction in any medium or format, as long as you give appropriate credit to the original author(s) and the source, provide a link to the Creative Commons license and indicate if you modified the licensed material. You do not have permission under this license to share adapted material derived from this chapter or parts of it. solving urban problems through innovative approach. JICA Research Institute, Tokyo, pp 205-226

Rivas H (2011) Analyses of capacity development processes for urban planning and (re)development in Medellín and Colombia: final report. JICA, Tokyo

Rojas Everhard MC (2018) Land readjustment within the context of partial plans in Colombia. In: de Souza F, Ochi T, Hosono A (eds) Land readjustment: solving urban problems through innovative approach. JICA Research Institute, Tokyo, pp 116-122

Sato M (2013) A fresh look at capacity development from insiders' perspective: a case study of an urban redevelopment project in Medellin, Colombia. JICARI working paper 60. JICA Research Institute, Tokyo Sorensen A (2009) Prefácio [Preface]. In: Souza FF (ed) Método de Planejamento Urbano: Projetos de Land Readjustment e Redesenvolvimento Urbano [Method of urban planning: projects of land readjustment and urban redevelopment]. Brazil: Paulo's Comunicacao, Sao Paulo

World Bank (2016) World development report 2016: digital dividends. World Bank, Washington, DC

Yanase N (2018) Land readjustment and post-disaster reconstruction in Japan. In: de Souza F, Ochi T, Hosono A (eds) Land readjustment: solving urban problems through innovative approach. JICA Research Institute, Tokyo, pp 63-78

The images or other third party material in this chapter are included in the chapter's Creative Commons license, unless indicated otherwise in a credit line to the material. If material is not included in the chapter's Creative Commons license and your intended use is not permitted by statutory regulation or exceeds the permitted use, you will need to obtain permission directly from the copyright holder. 